\title{
Research on the Teachers' Reasons and Differences of Students' Recessive Truancy under the Background of College English Class
}

\author{
Lei Qin \\ School of Applied Foreign Language Studies \\ Shandong University of Finance and Economics \\ Jinan, Shandong, China
}

\begin{abstract}
This paper explores the teachers' factors which cause students' recessive truancy in the college English class by using factor analysis, and finds differences about the teacher's influences between the freshmen group and the sophomore group through independent-sample test. This paper also puts forward effective measures from the angles of teaching conception and model, teaching content, teaching methods, teachers' development and teachers' personal charisma to reduce or eliminate the problem of recessive truancy.
\end{abstract}

\section{Keywords-recessive truancy; teacher's factors; differences}

\section{INTRODUCTION}

Students' recessive truancy is a common phenomenon in the college English classes. Recessive truancy brings much negative influences on students, teachers and the society. Under such circumstances, teaching process will be easily in disorder, teachers' enthusiasm will be hurt greatly, teaching resources will be wasted and the targets of college English course will not be achieved successfully. But recessive truancy is not paid much attention by the society and teachers and many college English teachers show their acquiescence to recessive truancy in the college English classes. So teachers' attitudes further encourage students' recessive truancy intention and actual behavior.

Fund Project: This paper is the periodical research result of Shandong Social Science Planning Project: Emotional Teaching Research under the New Model of College English Teaching Background, project number: 11CWZJ30.

In the research field, 1180 records will be found with the topic truancy through CNKI on October 27, 2016, 125 records will be found with the key words recessive truancy, and among them only 3 articles are about college English teaching. The researchers analyze the reasons of recessive truancy from three aspects: students, teachers' teaching and universities' management. Articles also put forward corresponding solutions. For example: The hidden reasons for College Students Recessive Truancy (Zhang Saibin, 2008: 155-156), The Strategies for Solving College Classroom Silence and Truancy (Cheng Shuhua, 2009: 94-96), The Survey about the Current Situation of University Students Recessive Truancy (Zhao Nan,
2010: 293-294), The Survey and Research of Recessive Truancy in College English Class(Cai Ying, 2011: 26-29), and Research on the Reasons and Strategies of the Crisis in the College English Class(Si Xiaorong, 2016:148-150).

But these researches features investigations and Empirical discussion. The investigations are in small scale and shallow level and the teaching strategies are limited. No researchers discuss the reasons of recessive truancy from teachers' factors, let alone college English teachers. College English teachers are the organizers and guides of English classes. They are responsible for students' Recessive truancy. So it is urgent and necessary to probe college English teachers' factors influencing students' recessive truancy. The research is important for practice and theory of college English teaching.

\section{RESEARCH DESIGN}

\section{A. Research Problem}

Through scientific sampling and careful analysis, this paper hopes to solve the following problems: what are the college English teachers' factors which influence students' recessive truancy? What are the influencing differences between freshmen and sophomores? What strategies should teachers adopt to decrease or get rid of students' recessive truancy in the college English class?

\section{B. Subjects}

The subjects of this research are freshmen and sophomores of non-English major from one university of Shandong Province. "Table I" is about the basic information of the subjects.

TABLE I. BASIC INFORMATION OF THE SUBJECTS

\begin{tabular}{|c|l|l|l|l|}
\hline & $\begin{array}{c}\text { freshme } \\
\mathbf{n}\end{array}$ & $\begin{array}{c}\text { sophomo } \\
\text { re }\end{array}$ & male & female \\
\hline $\begin{array}{c}\text { open-ended } \\
\text { investigation }\end{array}$ & 172 & 112 & 137 & 157 \\
\hline close investigation & 167 & 107 & 123 & 151 \\
\hline
\end{tabular}




\section{Questionnaire Survey}

Questionnaire survey includes two phases. The first phase is the open-ended questionnaire survey with only one question: what are teachers' factors influencing your recessive truancy in the college English class? 300 questionnaires were sent to freshmen and sophomores, 284 valid responses were returned. Through analysis and integration, 23 teachers' factors were collected.

The second phase is the close investigation. According to the 23 teachers' factors got from the first phase, Questionnaire about College English Teachers' Factors Influencing Students' Recessive Truancy is designed. The questionnaire includes two parts. The first part is about students' personal information, including sex, grade and attitude towards recessive truancy. The second part consists of the 23 teachers' factors. Adopting 5 points Likert scale, the answers are sorted according to the strength of the sequence of consent. The close investigation was carried on during April, 2016. 300 questionnaires were sent to freshmen and sophomores, 274 valid responses were returned.

\section{Research Method}

The questionnaire data is analyzed by SPSS (13.0). 1 item with obscure differentiation is deleted after item analysis (I19, $\mathrm{P}=0.136>0.05) .22$ items' Cronbach's alpha is .826 . Then go ahead with the following analysis: a, describing statistics to decide which test should be used; $b$, analyzing factors to find main common factors; c, analyzing reliability to testify the high reliability of the questionnaire items and the common factors; $d$ by using independent-sample $\mathrm{t}$ test, testing each common factor's different influences on freshmen and sophomores.

\section{ANALYSIS}

\section{A. College English Teachers' Factors Influencing Students' Recessive Truancy}

First, descriptive analysis was made. "Table II" The means of most items are above 2.5. It shows that students agree with the reasons described by the questionnaire items, and at the same time it expresses the variety of teachers' reasons. So it is necessary to carry on factor analysis to obtain several common factors.

After the first factor analysis, the fourth common factor contains two items I3 and I5, the fifth common factor contains one item I2, the sixth common factor contains one item I17. Because the above factors contain too few items, the above few items were deleted and the second factor analysis was conducted.

The result of KMO and Bartlett' $\mathrm{s}$ test: $\mathrm{KMO}=0.896$ $(>0.5)$, Sig. $=0.000 \quad(<0.05)$. Factor analysis can be carried out. Using Principal Component Analysis, 3 common factors were extracted. "Table III"
TABLE II. DESCRIPTIVE DATA

\begin{tabular}{l|l|l|l|l}
\hline \multicolumn{1}{c|}{ Item } & \multicolumn{1}{|c|}{ Mean } & $\begin{array}{c}\text { Standard } \\
\text { Deviation }\end{array}$ & Skewness & Kurtosis \\
\hline $\mathrm{I} 1$ & 3.5584 & 1.10206 & -.894 & .079 \\
\hline $\mathrm{I} 2$ & 3.3333 & 2.59430 & 12.209 & 182.517 \\
\hline $\mathrm{I} 3$ & 3.0547 & 2.61734 & 12.137 & 180.594 \\
\hline $\mathrm{I} 4$ & 3.0730 & 1.16503 & -.017 & 1.004 \\
\hline $\mathrm{I} 5$ & 2.5657 & 1.16310 & .381 & -.971 \\
\hline $\mathrm{I} 6$ & 3.1642 & 1.20349 & -.320 & -1.011 \\
\hline $\mathrm{I} 7$ & 2.7336 & 1.11525 & .238 & -.747 \\
\hline $\mathrm{I} 8$ & 3.0109 & 1.19364 & .031 & -1.166 \\
\hline $\mathrm{I} 9$ & 2.7336 & 1.21883 & .400 & -.909 \\
\hline $\mathrm{I} 10$ & 2.3029 & 1.13205 & .818 & -.173 \\
\hline $\mathrm{I} 11$ & 3.1277 & 1.22329 & -.282 & -1.066 \\
\hline $\mathrm{I} 12$ & 3.3467 & 1.19838 & -.412 & -.904 \\
\hline $\mathrm{I} 13$ & 3.3832 & 1.16852 & -.548 & -.579 \\
\hline $\mathrm{I} 14$ & 3.0989 & 1.15416 & -.108 & -1.048 \\
\hline $\mathrm{I} 15$ & 2.0839 & 1.19073 & 1.056 & .152 \\
\hline $\mathrm{I} 16$ & 2.2555 & 1.14852 & .759 & -.293 \\
\hline $\mathrm{I} 17$ & 2.9781 & 2.01448 & .9 .902 & 137.353 \\
\hline $\mathrm{I} 18$ & 2.4197 & 1.10731 & .465 & -.739 \\
\hline $\mathrm{I} 20$ & 2.8431 & 1.09319 & .027 & -.918 \\
\hline $\mathrm{I} 21$ & 2.6131 & 1.08771 & .283 & -.357 \\
\hline $\mathrm{I} 22$ & 2.7044 & 1.10453 & .293 & -.855 \\
\hline $\mathrm{I} 23$ & 2.5949 & 1.05531 & .285 & -.759 \\
\hline & & & & \\
\hline
\end{tabular}

TABLE III. QUESTINNAIRE ITEMS AND FACTOR LOADING

\begin{tabular}{|c|c|c|}
\hline $\begin{array}{c}\text { Factors } \\
\text { and alpha }\end{array}$ & Items & $\begin{array}{l}\text { Factor } \\
\text { loading }\end{array}$ \\
\hline $\begin{array}{c}\text { Teaching } \\
\text { methods } \\
\text { and } \\
\text { contents } \\
\alpha=.840\end{array}$ & $\begin{array}{l}\text { T13. Teaching is not interesting } \\
\text { T12. Hot issues are not talked much } \\
\text { T11. Teachers are prim, short of } \\
\text { enthusiasm } \\
\text { T6. Teaching material is textbook, out of } \\
\text { date } \\
\text { T14. Teaching contents are not practical, } \\
\text { and are not helpful for examination and } \\
\text { finding a job } \\
\text { T1. Teaching methods are dull } \\
\text { T8. Teachers seldom communicate with } \\
\text { students }\end{array}$ & $\begin{array}{l}.814 \\
.794 \\
.652 \\
.624 \\
.598 \\
.575 \\
.515\end{array}$ \\
\hline $\begin{array}{c}\text { Teaching } \\
\text { attitude } \\
\text { and ability } \\
\alpha=.842\end{array}$ & $\begin{array}{l}\text { T15. Teachers' state mind is not stable } \\
\text { and negative } \\
\text { T16. Too much nonsense, waste time } \\
\text { T10. Teachers' English proficiency is not } \\
\text { good } \\
\text { T22. Teaching speed is not proper } \\
\text { T9. teachers can not express and explain } \\
\text { clearly } \\
\text { T18. Not kind, difficult to communicate } \\
\text { T21. not good at multi media }\end{array}$ & $\begin{array}{l}.799 \\
.757 \\
.714 \\
.673 \\
.653 \\
\\
.644 \\
.388\end{array}$ \\
\hline $\begin{array}{l}\text { Class } \\
\text { activities } \\
\text { and } \\
\text { teachers } \\
\text { reaction } \\
\alpha=.679\end{array}$ & $\begin{array}{l}\text { T23. seldom questioning and testing } \\
\text { T20. teachers stand in front of the class } \\
\text { most of time } \\
\text { T7. teacher do not pay much students } \\
\text { reactions } \\
\text { T4. Few activities, students have few } \\
\text { opportunities to practise }\end{array}$ & $\begin{array}{l}.795 \\
.687 \\
.599 \\
.500\end{array}$ \\
\hline
\end{tabular}

The first common factor is teaching methods and contents. It contains 7 items. I1, T8, T11 and T13 are about teaching methods. I1 and I13 prove that catching students' interests are decisive for English class. I8 reflects the importance of communication with students. I6、I12 和 I14 tell us interesting, hot and practical knowledge is welcomed. The second common factor is teaching attitude and ability. Teaching should avoid 
too much personal emotion and nonsense. A good college English teacher should have the following qualities: high English proficiency, dealing with teaching materials skillfully, good at multi-media. The third factor shows that few activities and teachers' indifference to students' reaction would decrease students' study enthusiasm.

\section{B. Differentiation Analysis on Different Students Group}

Do the three common factors have different influences on freshmen and sophomores? Independent-sample $\mathrm{t}$ tests are made. Factor1: $\mathrm{p}=0.021<0.05$; factor 2 : $\mathrm{p}=0.0: 00<0.05$; factor3 : $\mathrm{p}=0.017<0.05$ 。 So the three factors' different influences on freshmen and sophomores are significant. Does each item contained in the three common factors influence freshmen and sophomores differently? Further Independentsample $\mathrm{t}$ tests are also made.

$\mathrm{P}$ values of I1, I11 $\mathrm{I} 12$ and I14 are 0.001、0.000、0.040、 0.034 , smaller than 0.05 . This indicates freshmen and sophomores have different ideas about the four items. Sophomores' means are bigger than freshmen' s means, and this shows that sophomores pay more attention to practical teaching material, innovative teaching forms and teachers' ability to encourage. After one year's English study, sophomores are familiar with teaching model, teachers and examinations. If the college English classes are still as usual, recessive truancy is a matter of fact. Also sophomores are beginning to think quietly about the function of English for their future. They hope more to acquire knowledge helpful for their studying abroad and finding a job, etc. Only one textbook can not meet students' needs. Freshmen are in the course of familiarizing; their needs of change are weak.

P values of 19, I10, I15 and I16 are all 0.000 , smaller than 0.05. This indicates freshmen and sophomores have different ideas about the four items. Freshmen's means are bigger than sophomores' means. It reflects that freshmen care more about teachers' teaching attitude and ability. College life is new and mysterious for the freshmen, and the reliance on teachers formed in the middle school is not entirely eliminated. Freshmen rely more on teachers. Sophomores have gradually got rid off the psychological base of depending on teachers. They have their own thoughts, plan and attitudes.

$\mathrm{P}$ values of I4 and I20 are 0.004 and 0.020 , smaller than 0.05 . So freshmen and sophomores have different ideas about the two items. Sophomores' means are bigger than freshmen's means. The result expresses sophomores' urgent needs to improve their ability to use English and to communicate with teachers in English. Meanwhile, with the increasing difficulty of the course, with students preparing for CET, teachers, may reduce classroom time. This is a contradiction. If teachers can not meet students' needs, students would probably have the thought of recessive truancy.

\section{CONCLUSIONS AND IMPLICATIONS}

\section{A. Conclusions}

Conclusions can be drawn from the above analysis:
College English teachers' factors influencing students' recessive truancy: Teaching methods and contents, teaching attitude and ability, and class activities and teachers' reaction. The above three factors have different influences on freshmen and sophomores: Freshmen rely more on teachers, while sophomores have more demands for teaching forms, innovative teaching and class interactions.

\section{B. Implications}

This paper also provides some implications:

1) Reform teaching idea and teaching model: The National Medium-and Long-term Program for Education Reform and Development says: regard students as the main body, teachers as the guide, bring the initiative of the students into full play (2010). But for a long time, college English teaching has been teacher-centered, students mainly aims to understand and remember where the knowledge from the teachers. Teaching ignores the objective laws of language teaching and student physical and mental development ignores the dynamic role of the study body. Reform and innovation are powerful and decisive driving forces of educational development and are also the solution for students' recessive truancy.

2) Form renewal mechanism of teaching material: Update teaching contents, and pay more attention to practical, enlightening and interesting contents. Teaching materials must correspond with students' interests and future development. Then students would avoid recessive truancy and develop their abilities.

3) Innovate teaching methods: No matter how good teaching materials are, how valuable the textbook is, without a good teacher, the class would be boring and lifeless. According to different students and teaching materials, a good teaching can use heuristic, inquiry, discussion, participatory teaching methods to help students to learn, to encourage students' curiosity and interests, and then create a free and creative environment.

4) Improve educational and teaching comprehensive ability: Establish the concept of lifelong learning, learning about the essence of college English teaching reform, understand and implement the reform requirements; expand professional knowledge of English language, foreign language teaching theory, pedagogy, psychology, network multimedia and other areas; enhance verbal skills, English practice ability, multimedia operating capability, ability to communicate with students, research capacity and regulatory capacity, so as to improve the skills to meet the actual needs of teaching and research.

5) Enhance the teachers' charisma: Responsibility, dedication, fairness, tolerance, humor, humble, generous and patience are necessary for English teaching. The core is the "Help", including cultivating students' ability, enhancing students' self-confidence, easing anxiety, overcoming bad emotional state and so on. Teachers with outstanding 
personality traits have invisible charismata, stimulating their interests in learning English and promoting good personality.

6) To understand the differences of students, teach students in accordance with their aptitude: Respect individual differences of students, respect students' needs at different stages when teaching college English, and select the appropriate methods to develop targeted instructional content.

Limitations of this paper are that the subjects are limited to a university, and the survey does not choose universities from different types and levels. Future research should consider the comprehensiveness of the sample to provide a useful reference for college English teaching.

\section{REFERENCES}

[1] Cai Ying. The Survey and Research of Recessive Truancy in College English Class [J]. English Teachers, 2011(10).

[2] Cheng Shuhua. The Strategies for Solving College Classroom Silence and Truancy [J]. Heilongjiang Researches on Higher Education, 2009(7).

[3] Si Xiaorong. Research on the Reasons and Strategies of the Crisis in the College English Class[J]. Journal of Tianzhong, 2016(3):148-150.

[4] The National Medium-and Long-term Program for Education Reform and Development, http://news.xinhuanet.com/edu/201007/29/c_12389320.htm

[5] Zhang Saibin. The hidden reasons for College Students Recessive Truancy [J].Higher Education Forum, 2008(3)

[6] Zhao Nan. The Survey about the Current Situation of University Students Recessive Truancy [J]. Social Sciences Review, 2010(4). 